\title{
What are the problems of the red meat processing industry?: A case study from Turkey
}

\author{
Duygu TOSUN ${ }^{1 *}$ (D), Nevin DEMİRBAŞ
}

\begin{abstract}
The red meat processing industry has an important place in the food industry in Turkey. However, there are significant problems that limit the contribution of the industry to the red meat sector, particularly with regard to the livestock enterprises which are the source of raw materials. The aim of this paper is to identify the problems of the red meat processing industry, and to suggest solutions to these problems, through a case study of Izmir and Afyonkarahisar provinces, which together provide a useful representation of the structural characteristics typically found in the red meat sector in Turkey. In this study, a total of 71 face-to-face surveys were conducted with the managers of slaughterhouses (19), meat combines (13) and meat and meat product processing plants (39). The current situation of the enterprises and their problems were examined, particularly with regard to raw material supply, production and marketing. High and unstable prices of raw materials, combined with high costs, are the major problems. In order to resolve the problems in the industry, horizontal and vertical integration needs to be improved throughout the entire supply chain, starting from livestock farming through to the point where the end product reaches the final consumer.
\end{abstract}

Keywords: red meat; red meat products; slaughterhouse; processing plant; Turkey.

Practical Application: These findings can guide decision makers to set strategies for the development of the red meat processing industry in Turkey and other developing countries.

\section{Introduction}

The agricultural sector is of strategic importance in Turkey, as in the rest of the world, due to its crucial contribution as a provider of nutrition for the population. In line with increases in the global population, the demand for food is also increasing, including red meat (Yavuz et al., 2013; Food and Agriculture Organization of the United Nations, 2014; Turkey, 2015; Uçum \& Gülçubuk, 2018). Red meat is important in human health and nutrition (Williamson et al., 2005; Wyness, 2016). Previous studies have emphasized that red meat is a source of high biological value protein, iron, zinc and various B vitamins (Bender, 1992; Scollan et al., 2006; Pereira \& Vicente, 2013).

The recommended protein intake for an adult is 0.83 grams per kilogram of body weight per day (World Health Organization, 2007; European Food Safety Authority, 2012). Although total protein consumption per capita is sufficient in Turkey, most of the protein is plant-based. Animal protein consumption is not adequate (Bilgiç \& Yen, 2013; Turkey, 2014c). For the years $2015 / 2017$, average protein consumption per capita is 102.29 grams. Only $34.86 \%$ (34.86 grams) of daily protein consumption per capita is derived from proteins of animal origin. Average daily animal protein consumption per person across the world is 32.56 grams, 60.96 grams in the European Union (28) and 14.04 grams in least developed countries. In 2017, Turkey was ranked 89th out of 172 countries in the world in terms of animal protein consumption (Food and Agriculture Organization of the United Nations, 2020).
Ensuring food security is a priority for food policies in every country, and Turkey is no exception. However, it has not reached self-sufficiency in red meat production (Turkey, 2014a). Between 2008 and 2017 in Turkey, average consumer beef prices increased by $34.65 \%$ while producer prices increased by $20.65 \%$ (Turkish Statistical Institute, 2018). Due to the increase in red meat prices, the industry has difficulty providing sufficient raw materials and consumers have difficulty accessing the red meat and meat products they need at reasonable prices. As a result, importation of cattle and beef products began in 2010 and has continued at irregular intervals (Turkey, 2010a, 2018a).

In Turkey, the red meat industry is seen as including the whole process starting from the slaughter of animals in slaughterhouses through to the packaging of final products for sale. The main enterprises operating in the industry are (i) slaughterhouses; (ii) meat combines (which both slaughter animals and process meat and meat products); and (iii) meat and meat product processing plants (State Planning Organization, 2001). In order to ensure safe and healthy products are consumed, it is important to constantly evaluate agricultural raw materials in the industry before presenting them to consumers.

The red meat processing industry is important in the food industry in Turkey. According to NACE Rev_2 classification, the value of the contribution to the food industry of the red meat and poultry meat industry combined is $10.41 \%$, according to the average for the years 2015 to 2017 (Turkish Statistical 
Institute, 2018). Despite its place within the food industry, the capacity utilization rate of the red meat processing industry is not at a satisfactory level (Turkey, 2014b; Demirkol \& Azabağaoğlu, 2017). Minimal utilization of existing installed capacity has negative effects on enterprises and therefore on the national economy (Demirbaş \& Talim, 1999; Saygın \& Demirbaş, 2017). The capacity utilization rate has a significant impact on the profitability and productivity of enterprises (Aral \& Sakarya, 2009; Demirkol \& Azabağaoğlu, 2017). For this reason, our aim in this study is to identify the problems of enterprises operating in the red meat processing industry and to develop solutions for these problems.

\section{Materials and methods}

This study was carried out in the west of Turkey, in the provinces of Izmir and Afyonkarahisar. According to the 2012 Food Industry inventory which provides data on slaughterhouses only, Izmir province ranks 4th and Afyonkarahisar 7 th for total red meat production in Turkey. These are also the key provinces for red meat production in the country's Aegean Region. According to the NUTS (Nomenclature of territorial units) classification, the Aegean Region contributed $14.66 \%$ of the total volume of red meat production in Turkey and, in turn, $60.62 \%$ of that amount was produced in Izmir and Afyonkarahisar provinces.

The information on enterprises was obtained from the Afyonkarahisar and Izmir Directorate of Provincial Food Agriculture and Livestock. It was planned that face-to-face surveys would be conducted with the managers of all of these enterprises. But only $70.3 \%$ of the surveys were completed, as not all managers were willing to participate in the survey. A total of 71 face-to-face surveys were conducted with the managers of slaughterhouses (19), meat combines (13) and meat and meat product processing plants (39) in the centers and county districts of Afyonkarahisar and Izmir Provinces.

The study identifies a range of problems, especially with regard to raw material supply, production and marketing. Particular consideration is given to beef, specifically relating to problems with animal husbandry and raw materials, since $86.53 \%$ of the production of red meat in Afyonkarahisar and Izmir is from beef (Turkey, 2012). A Five-Point Likert Scale was used to measure the problems of enterprises, where 1 indicates "strongly disagree" and 5 indicates "strongly agree" (Malhotra, 2010). Enterprises were grouped into three types; slaughterhouses, meat combines and meat and meat product processing plants. Differences between groups in terms of enterprise types were determined. For continuous variables, a normal distribution test was applied by using the Kolmogorov-Smirnov test. For non-parametric variables, the Kruskal-Wallis test was carried out to compare differences between groups in terms of enterprises types (Newbold, 1995; Field, 2009). The interviews with managers were held over a period from February 2015 to July 2015.

\section{Structure of the red meat processing industry in Turkey}

According to the 2012 Food Industry inventory, there were 577 slaughterhouses in Turkey for bovine animals and 523 slaughterhouses for sheep and goats. The total installed capacity for the slaughter of bovine animals is approximately 174 thousand head per day and total annual production is approximately 569 thousand tons (Table 1).

The same inventory provides information on the range of production enterprises operating in the red meat and meat products industry. There were 502 involved in raw red meat processing, 350 in producing heat-treated fermented sausage-like products, 313 meatballs, 183 fermented sausage, 133 salami, 121 sausage and 122 producing pastrami. The most- produced red meat products were meatballs, sausages, roast meats and salami. However, it is clearly evident that the rate of capacity utilization in the meat and meat products industry is low. The rate was $54.28 \%$ for raw red meat, $75.24 \%$ for meatballs, $17.23 \%$ for fermented sausage, $45.99 \%$ for heat-treated fermented sausage-like products and $27.62 \%$ for salami (Table 2 ).

\section{Results}

\subsection{Characteristics of red meat processing industry enterprises and their managers}

The average age of managers was 44 , with 14 years of education. On average, managers' occupational experience was 14.5 years, with 12.7 years in the particular enterprise. Therefore, it is clear that there is no shortage of experience amongst managers in the sector. There were statistically significant differences among enterprises in terms of the education level of managers. The level was highest (14.84 years) in slaughterhouses and lowest in meat and meat product processing plants (12.85) (Table 3).

The enterprises had been operating in the sector for around 21 years. $35.21 \%$ of the enterprises were limited liability companies, $22.54 \%$ were privately owned enterprises, $21.13 \%$ were municipal enterprises, $18.31 \%$ were joint-stock companies and $2.82 \%$ were cooperative enterprises. Both slaughterhouses and meat and meat product processing plants in Izmir province were widely-dispersed in terms of districts where they operate. In Afyonkarahisar, except for certain districts, most enterprises operating in the sector were concentrated in the Afyonkarahisar Organized Industrial Zone in the province center.

Table 1. Slaughterhouses in Turkey (2012).

\begin{tabular}{lcccc}
\hline & Number of Slaughterhouses & $\begin{array}{c}\text { Installed capacity } \\
\text { (head/day) }\end{array}$ & $\begin{array}{c}\text { Production } \\
\text { (carcass/year) }\end{array}$ & $\begin{array}{c}\text { Production } \\
\text { (tonnes/year) }\end{array}$ \\
\hline Bovine animals & 577 & 173753 & 2193987 & 568810 \\
Sheep and goats & 523 & 215111 & 3329527 & 72301 \\
\hline
\end{tabular}

Source: Turkey (2012). 
Table 2. Read meat and meat products enterprises in Turkey (2012).

\begin{tabular}{|c|c|c|c|c|}
\hline Red Meat and Meat Products & $\begin{array}{l}\text { Number of } \\
\text { Enterprises }\end{array}$ & $\begin{array}{l}\text { Installed capacity } \\
\text { (tonnes/year) (1) }\end{array}$ & $\begin{array}{c}\text { Production (tonnes) } \\
\text { (2) }\end{array}$ & $\begin{array}{l}\text { Capacity Utilization } \\
\text { Rate }(\%)(2 / 1)\end{array}$ \\
\hline Raw red meat & 502 & 3780358.53 & 2051914.65 & 54.28 \\
\hline Doner $^{1}$ & 116 & 40652.85 & 17697.25 & 43.53 \\
\hline Sauced, cured, marinated and flavored meat piece & 38 & 5189.00 & 2560.00 & 49.34 \\
\hline Fermented sausage & 183 & 171209.97 & 29502.88 & 17.23 \\
\hline Heat treated fermented sausage - like product & 350 & 91065.22 & 41877.19 & 45.99 \\
\hline Sausage & 121 & 58395.79 & 13528.14 & 23.17 \\
\hline Salami & 133 & 56467.63 & 15595.84 & 27.62 \\
\hline Smoked Meat & 27 & 1345.00 & 223.58 & 16.62 \\
\hline Coated meat and meat products & 4 & 4772.00 & 4673.88 & 97.94 \\
\hline Dried meat & 3 & 73.00 & 3.80 & 5.21 \\
\hline Kokorec $^{2}$ & 15 & 5792.00 & 3361.00 & 58.03 \\
\hline Jelly tripe & 10 & 1114.00 & 361.00 & 32.41 \\
\hline Others & 77 & 38774.97 & 18300.49 & 47.20 \\
\hline Mechanically separated red meat & 5 & 1902.00 & 1599.00 & 84.07 \\
\hline
\end{tabular}

${ }^{1}$ Traditional meat production made of beef, lamb or veal and seasoned with spices; ${ }^{2}$ Product made of sheep or lamb intestine. Source: Turkey (2012).

Table 3. General characteristics of the managers.

\begin{tabular}{lcccc}
\hline \multicolumn{1}{c}{ Characteristics of managers } & Slaughterhouses & Meat combines & $\begin{array}{c}\text { Meat and meat } \\
\text { product processing } \\
\text { plants }\end{array}$ & Average \\
\hline Age (year) & 42.84 & 42.00 & 44.64 & 43.68 \\
Education (year) & 15.37 & 14.23 & 12.85 & 13.77 \\
Occupational experience (year) & 14.84 & 17.23 & 18.82 & 13.46 \\
Time in the enterprise (year) & 10.44 & 15.00 & 13.01 & 12.72 \\
\hline
\end{tabular}

${ }^{*}$ Kruskal Wallis test was significant for $\mathrm{p}<0.05$.

45.07\% of enterprises had fewer than 10 employees, $30.99 \%$ had 11-25 employees, $9.86 \%$ had $26-49$ employees and only $14.08 \%$ of enterprises had 50 or more employees. From this, it can be seen that enterprises are usually small and medium sized. Under the Veterinary Services, Plant Health, Food and Feed Law No. 5996, it is obligatory to employ a veterinarian in meat combines and slaughterhouses and a veterinarian or a food engineer or an agricultural engineer (graduate from food department) in meat and meat product processing plants plants (Turkey, 2010b). In this study it was found that all slaughterhouses and meat combines employed a veterinarian. And $51.28 \%$ of the meat and meat product processing plants employed a food engineer and $69.23 \%$ a veterinarian.

In $63.33 \%$ of the slaughterhouses, bovine animals, sheep, and goats were slaughtered in the same plant, while in $36.67 \%$ only bovine animals were slaughtered. In $27.45 \%$ of the enterprises processing meat and meat products, both poultry meat and red meat were processed. Raw meat was produced in $45.10 \%$ of the enterprises, fermented sausage in $78.43 \%$, salami in $29.41 \%$, sausage in $27.45 \%$, pastrami in $23.53 \%$, meatballs in $21.57 \%$, roasting in $13.73 \%$, doner in $13.73 \%$ and jambon in $9.80 \%$. However, the capacity utilization rate was low in both slaughterhouses and in enterprises processing meat and meat products.

\subsection{Problems of red meat processing industry enterprises}

According to our survey of managers, the most serious problem for livestock enterprises was the negative effect of high feed prices on production. This was followed by inadequacy of rangeland, insufficient agricultural organization in beef cattle 
farming, difficulty in finding fattening material, inadequate extension services, the small number of beef cattle enterprises and inadequate control of animal movements (Table 4).

Unstable carcass meat prices were seen as the chief problem for managers in obtaining raw material. This was followed by high meat prices and prices that were not determined according to quality. Managers did not agree with the statement about the lack of an adequate cold chain in carcass meat production and distribution. This can be regarded as an indicator of significant progress in terms of ensuring cold chain conditions in the sector. There were statistically significant differences among enterprises with regard to the statements" "carcass meat prices are unstable", "carcass meat prices are high", "the amount of carcass meat is insufficient" and "carcass meat quality is inadequate". The level of agreement to these statements was higher in the meat combines (Table 5).

Table 4. Managers' views on problems related to livestock enterprises.

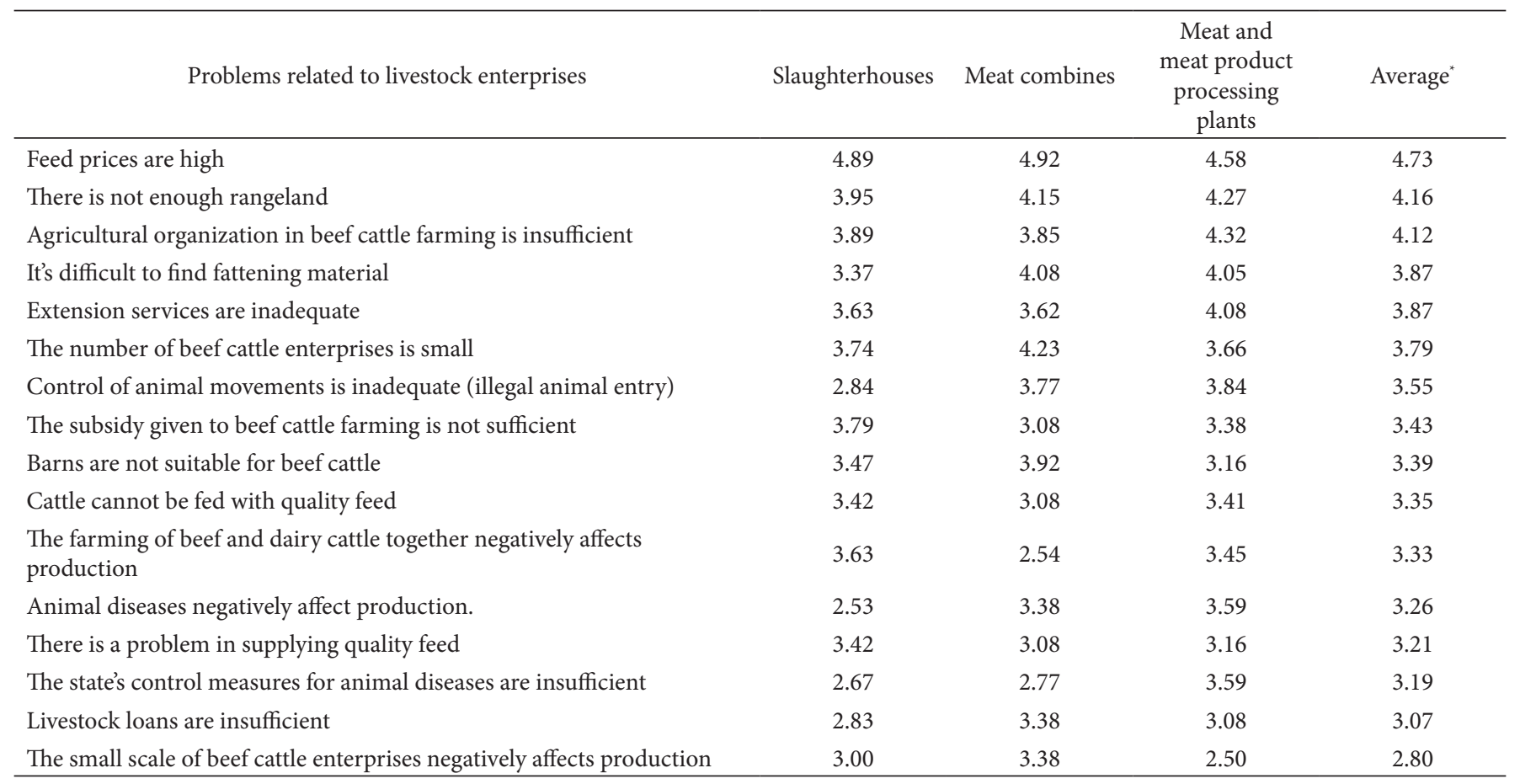

${ }^{*} 1$ Strongly disagree and 5 Strongly agree.

Table 5. Managers' views on problems related to raw material.

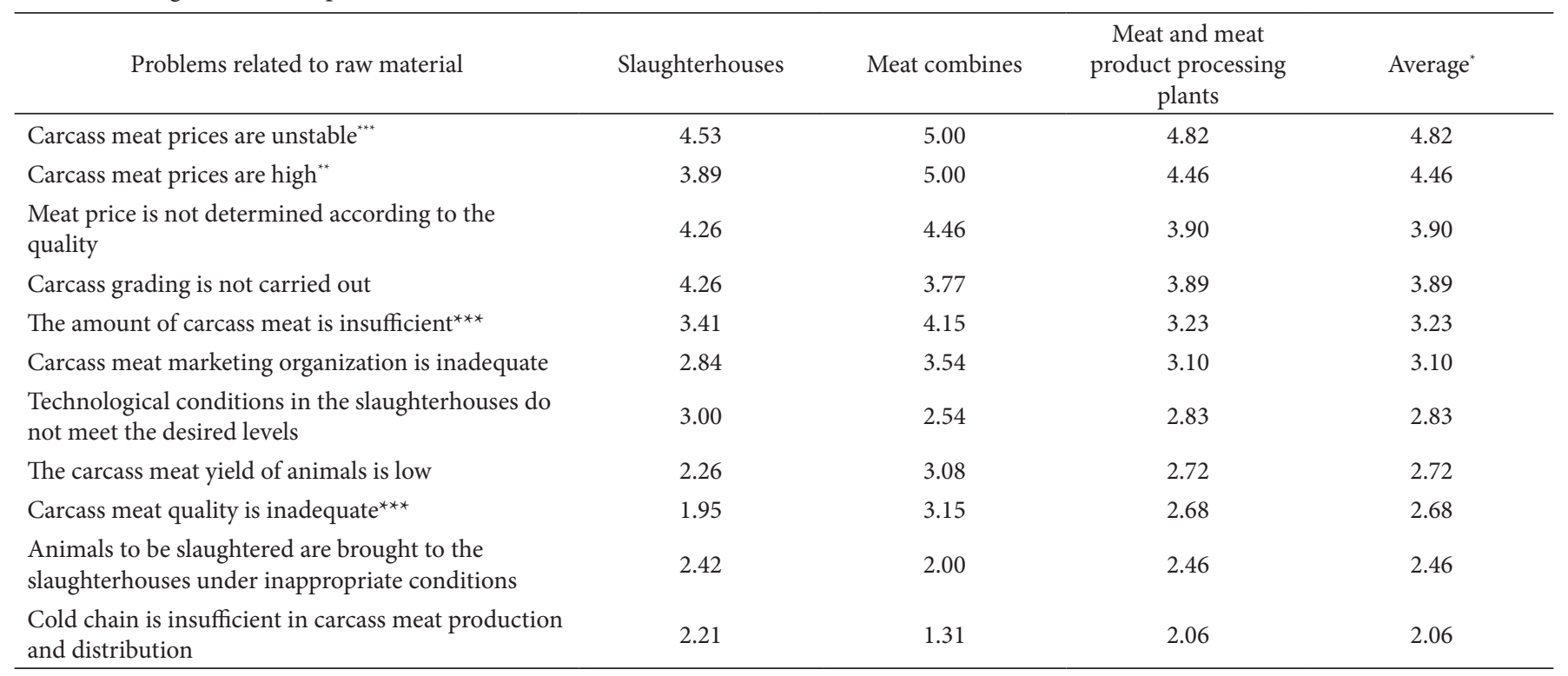

${ }^{*} 1$ Strongly disagree and 5 Strongly agree; ${ }^{* *}$ Kruskal Wallis test was significant for $\mathrm{p}<0.05$; ${ }^{* *}$ Kruskal Wallis test was significant for $\mathrm{p}<0.1$. 
High financing costs and energy costs were the main problems reported by the managers in relation to production. There were statistically significant differences among enterprises with regard to the statement "the capacity utilization rate is low". The degree of agreement was lowest in the slaughterhouses (Table 6).

The managers reported that the main marketing-related problem was high logistics costs. This was followed by counterfeiting and adulteration of meat products (Table 7).

\section{Discussion}

Raw material makes up the largest portion of the production costs of red meat processing enterprises. High and unstable raw material prices directly affect the retail price of products and make it difficult for consumers to purchase these products. Difficulties in marketing directly affect the production volume and capacity utilization rate of the enterprises. Livestock enterprises are the main source of raw material for the red meat processing industry. Though Turkey has highly favorable conditions in terms of animal husbandry, structural issues and inconsistencies in policy implementation cause serious problems for livestock enterprises (Ağır \& Akbay, 2018; Kayikci et al., 2019). It is essential that these problems are resolved so that the required raw material can be supplied at a reasonable price and consumers can access the food they need at an affordable price.

The managers interviewed stated that high feed prices are the biggest problem for livestock enterprises. This is followed

Table 6. Managers' views on problems related to production.

\begin{tabular}{|c|c|c|c|c|}
\hline Problems related to production & Slaughterhouses & Meat combines & $\begin{array}{c}\text { Meat and meat } \\
\text { product processing } \\
\text { plants }\end{array}$ & Average \\
\hline Financing costs are high & 4.67 & 4.69 & 4.62 & 4.65 \\
\hline Energy costs are high & 4.42 & 4.69 & 4.54 & 4.54 \\
\hline Lack of qualified staff & 3.95 & 4.46 & 4.64 & 4.42 \\
\hline Tax rates are high & 4.06 & 4.08 & 4.38 & 4.24 \\
\hline There is unregistered production in the sector & 3.47 & 4.31 & 4.13 & 3.99 \\
\hline Labor costs are high & 3.53 & 4.08 & 4.10 & 3.94 \\
\hline Business and investment loans are insufficient & 3.94 & 3.23 & 3.87 & 3.76 \\
\hline The capacity utilization rate is low ${ }^{* *}$ & 2.58 & 3.54 & 3.97 & 3.52 \\
\hline Incentives related to production are insufficient & 3.65 & 3.15 & 3.39 & 3.41 \\
\hline There are many bureaucratic obstacles & 3.37 & 3.38 & 3.08 & 3.21 \\
\hline The infrastructure is inadequate & 2.50 & 1.54 & 1.82 & 1.94 \\
\hline $\begin{array}{l}\text { The location of the enterprise is not suitable for } \\
\text { production }\end{array}$ & 1.95 & 1.54 & 1.62 & 1.69 \\
\hline
\end{tabular}

${ }^{*} 1$ Strongly disagree and 5 Strongly agree; ${ }^{*}$ Kruskal Wallis test was significant for $\mathrm{p}<0.05$.

Table 7. Managers' views on marketing-related problems.

\begin{tabular}{|c|c|c|c|c|}
\hline Problems related to marketing & Slaughterhouses & Meat combines & $\begin{array}{c}\text { Meat and meat } \\
\text { product processing } \\
\text { plants }\end{array}$ & Average \\
\hline Counterfeiting and adulteration in meat products ${ }^{* *}$ & 3.53 & 4.62 & 3.85 & 3.91 \\
\hline Insufficient levels of demand for final goods & 3.19 & 3.15 & 2.92 & 3.03 \\
\hline There is a lack of information about the market & 3.53 & 2.62 & 2.66 & 2.87 \\
\hline Red meat has a promotion problem & 2.88 & 2.23 & 2.56 & 2.58 \\
\hline $\begin{array}{l}\text { The number of vehicles equipped for safe meat } \\
\text { transportation is insufficient }\end{array}$ & 2.00 & 1.77 & 1.64 & 1.75 \\
\hline
\end{tabular}

${ }^{*} 1$ Strongly disagree and 5 Strongly agree; ${ }^{* *}$ Kruskal Wallis test was significant for $\mathrm{p}<0.05$. 
by the lack of, or poor quality of, available rangeland. The major expense in the process of fattening cattle is the feed itself (Katz \& Boland, 2000; Arthur \& Herd, 2008; Saitone, 2018). It is generally agreed among managers that solving the issue of high feed costs is crucial to increasing the supply of red meat. This requires the continuation of forage crops production subsidies which are paid on a 'per hectare' basis (Turkey, 2018b). Also, to increase production and productivity, extension programs for forage production require to be improved for both crop and livestock farms. It is recommended that livestock husbandry should be integrated with forage crop production wherever feasible in order to reduce feed costs. Various studies have shown that provision of suitable grazing is highly beneficial in reducing feeding costs and lowering expenses (Taylor \& Field, 1995; Ball et al., 2008; Er \& Özçelik, 2016). For this reason, the quality of rangelands needs to be improved. Furthermore, improper use of rangelands should be prevented.

Our research shows that one of the most significant problems of enterprises in relation to raw material supply is unstable carcass meat prices. Unstable raw material prices have a significant negative impact on the production planning of enterprises. In addition, managers are faced with issues such as lack of carcass grading and price determination according to the quality of raw material. Carcass grading is not only crucial for the red meat processing industry but also in meeting consumers' expectations for food safety and quality (Unnevehr \& Bard, 1993; Verbeke et al., 2010; Aalhus et al., 2014). In Turkey, the carcass grading system needs to be implemented as soon as possible. To this end, the Ministry of Agriculture and Forestry has announced that a meat grading system will be implemented in Turkey by 2021 (Turkey, 2019). This should ensure industrialists and consumers will not have to pay high prices for low-quality meat. At the same time, pricing according to grading will serve to promote higher quality production.

High costs in relation both to production and marketing and fluctuations in input prices result in problems with sales and also lead to the requirement for increased financing for enterprises. For this purpose, measures should be taken to improve access to low-interest and long-term loans, and to provide ease of collateral for enterprises. A further problem in the red meat processing industry is a lack of qualified personnel. There is a need for qualified staff in both slaughterhouses and processing plants. The employment of qualified staff speeds up the time taken in the slaughtering process thus reduces costs (Kale et al., 2010). The personnel employed in slaughterhouses and processing plants should be educated and trained in all matters relating to production and food safety. This is a prerequisite not only for increasing production but for ensuring high quality and safe food production. To achieve this, short-term courses can be arranged through the provincial/district directorates of the Ministry of Agriculture and Forestry.

Due to issues in the industry with fraud and the adulteration of meat products, more effective control mechanisms must be established throughout the supply chain. This should involve frequent inspections at all stages of the process from production through to final consumption.

\section{Conclusion}

Small and medium sized enterprises which have low capacity utilization constitute the major part of the processing industry in Turkey. High and unstable prices of raw materials and high costs are the main problems for these enterprises. The raw material is supplied from livestock enterprises. Therefore, it is recommended that the problems of livestock enterprises are resolved in order to settle the issues of capacity utilization and production costs of the industry. Other important matters are: the need to increase the availability of low interest and long-term loan opportunities in the meat processing industry; implementing a carcass grading system; tightening controls and penalties imposed by the Ministry of Agriculture and Forestry; and increasing the number of qualified personnel in the field.

\section{Acknowledgements}

This study is part of the $\mathrm{PhD}$ thesis of the first author. The authors would like to thank all managers for their participation in the study.

\section{References}

Aalhus, J. L., López-Campos, Ó., Prieto, N., Rodas-González, A., Dugan, M. E. R., Uttaro, B., \& Juárez, M. (2014). Review: Canadian beef grading-opportunities to identify carcass and meat quality traits valued by consumers. Canadian Journal of Animal Science, 94(4), 545-556. http://dx.doi.org/10.4141/cjas-2014-038.

Ağır, H. B., \& Akbay, C. (2018). Factors affecting on the producers' utilization of beef cattle support. KSU Journal of Natural Sciences, 21(5), 738-744. http://dx.doi.org/10.18016/ksudobil.407625.

Aral, Y., \& Sakarya, E. (2009). A study on cattle kill-floor efficiency and measurement of labour productivity at the slaughter stages in some public slaughterhouses in Turkey. Journal of Turkish Veterinary Medical Society, 80(2), 3-12. Retrieved from https://dergipark.org. $\mathrm{tr} / \mathrm{tr} / \mathrm{pub} /$ vetheder/issue/34342/379356

Arthur, J. P. F., \& Herd, R. M. (2008). Residual feed intake in beef cattle. Revista Brasileira de Zootecnia, 37(spe), 269-279. http://dx.doi. org/10.1590/S1516-35982008001300031.

Ball, D. M., Ballard, E. N., Kennedy, M. L., Lacefield, G. D., \& Undersander, D. J. (2008). Extending grazing and reducing stored feed needs (Grazing Lands Conservation Initiative Publication, No. 8-01). Bryan, TX: NRCS. Retrieved from https://www.nrcs.usda.gov/wps/ PA_NRCSConsumption/download? cid=nrcseprd1455014\&ext=pdf

Bender, A. (1992). Meat and meat products in human nutrition in developing countries. FAO Food and Nutrition Paper, 53, 1-91. PMid:1300286.

Bilgiç, A., \& Yen, S. T. (2013). Demand for meat and dairy products by Turkish households: a Bayesian censored system approach. Agricultural Economics, 45(2), 117-127. http://dx.doi.org/10.1111/agec.12019.

Demirbaş, N., \& Talim, M. (1999). Türkiye'de et ve et ürünleri sanayiinde gelişmeler AB ile uyumda ortaya çıkabilecek sorunlar. Izmir: Izmir Chamber of Commerce.

Demirkol, C., \& Azabağaoğlu, M. O. (2017). Analysis of business structures on capacity usage in determining encountered problems of red meat industry in Turkey. Social Sciences Research Journal, 6(4), 359-369.

Er, S., \& Özçelik, A. (2016). The examination of economic structure of cattle fattening farms in Ankara province by factor analysis. Yuzuncu Yil University Journal of Agricultural Sciences, 26(1), 17-25. http:// dx.doi.org/10.29133/yyutbd.236283. 
European Food Safety Authority - EFSA. (2012). Scientific opinion on dietary reference values for protein. EFSA Journal, 10(2), 2557. http://dx.doi.org/10.2903/j.efsa.2012.2557.

Field, A. (2009). Discovering statistics using SPSS: introducing statistical method (3rd ed.). London: Sage Publications.

Food and Agriculture Organization of the United Nations - FAO. (2014). Meat consumption. Rome: FAO. Retrieved from http://www. fao.org/ag/againfo/themes/en/meat/background.html

Food and Agriculture Organization of the United Nations - FAO. (2020). FAOSTAT database. Rome: FAO. Retrieved from www.faostat.org

Kale, M. Ç., Aydın, E., Aral, Y., \& Cevger, Y. (2010). The research on investigation of factors affecting the production process on cattle slaughtering line in a private sector slaughterhouse. Veterinary Journal of Ankara University, 57(3), 179-183. Retrieved from http:// vetjournal.ankara.edu.tr/tr/issue/44739/556029

Katz, J. P., \& Boland, M. (2000). A new value-added strategy for the US beef industry the case of US Premium Beef Ltd. Supply Chain Management, 5(2), 99-110. http://dx.doi.org/10.1108/13598540010320018.

Kayikci, Y., Ozbiltekin, M., \& Kazancoglu, Y. (2019). Minimizing losses at red meat supply chain with circular and central slaughterhouse model. Journal of Enterprise Information Management, 33(4), 791816. http://dx.doi.org/10.1108/JEIM-01-2019-0025.

Malhotra, N. K. (2010). Marketing research: an applied orientation. Harlow: Pearson.

Newbold, P. (1995). Statistics for business and economics. Harlow: Prentice Hall.

Pereira, P. M. C. C., \& Vicente, A. F. R. B. (2013). Meat nutritional composition and nutritive role in the human diet. Meat Science, 93(3), 586-592. http://dx.doi.org/10.1016/j.meatsci.2012.09.018. PMid:23273468.

Saitone, T. L. (2018). Livestock and rangeland in California. In P. L. Martin, R. E. Goodhue \& B. D. Wright (Eds.), California agriculture dimensions and issues (Chap. 9, Giannini Foundation Information Series). Berkeley: Giannini Foundation of Agricultural Economics.

Saygın, Ö., \& Demirbaş, N. (2017). The current situation of red meat sector in Turkey and solution recommendations. Animal Production, 58(1), 74-80. http://dx.doi.org/10.29185/hayuretim.335515.

Scollan, N., Hocquette, J. F., Nuernberg, K., Dannenberger, D., Richardson, I., \& Moloney, A. (2006). Innovations in beef production systems that enhance the nutritional and health value of beef lipids and their relationship with meat quality. Meat Science, 74(1), 17-33. http://dx.doi.org/10.1016/j.meatsci.2006.05.002. PMid:22062713.

State Planning Organization. (2001). 8th five-year development plan, meat and meat products industry, special experts commission report. Ankara: SBB. Retrieved from http://www.sbb.gov.tr/wp-content/ uploads/2018/11/08_GidaSanayii_EtVeEtUrunleriSanayii.pdf

Taylor, R. E., \& Field, T. G. (1995). Achieving cow/calf profitability through low-cost production. In Proceedings of Range Beef Cow Symposium XIV. Gering, NE: University of Nebraska.

Turkey, Council of Ministers Decision. (2010a, April 30). Decision on the implementation of tariff containment in the importation of live cattle and beef without breeding to be used by the general directorate of meat and fish institution (No. 2010/373). Official Gazette of Turkish Republic. Retrieved from https://www.resmigazete.gov.tr/ eskiler/2010/04/20100430-6.htm

Turkey. (2010b, June 13). Veterinary services, plant health, food and feed law (No. 5996). Official Gazette of Turkish Republic. Retrieved from https://www.resmigazete.gov.tr/eskiler/2010/06/20100613-12.htm
Turkey, Ministry of Agriculture and Forestry. (2012). Food industry inventory data 2012. Ankara. Retrieved from https://www.tarimorman. gov.tr/Konu/1718/2012-y\%C4\%B11\%C4\%B1-g\%C4\%B1da-sanayienvanter-verileri

Turkey, Ministry of Development. (2014a). 10th development plan, efficiency and food safety in in agricultural structure, special experts commission report. Ankara: SBB. Retrieved from http://www.sbb. gov.tr/wp-content/uploads/2018/10/10_TarimsalYapi.pdf

Turkey, Ministry of Development. (2014b). 10th development plan, animal husbandry, special experts commission report. Retrieved from http:// www.sbb.gov.tr/wp-content/uploads/2018/10/10_Hayvancilik.pdf

Turkey, Ministry of Health. (2014c). Nutrition and Health Research of Turkey 2010 (Publication, No. 931). General Directorate of Health Research. Retrieved from https://hsgm.saglik.gov.tr/depo/birimler/ saglikli-beslenme-hareketli-hayat-db/Yayinlar/kitaplar/diger-kitaplar/ TBSA-Beslenme-Yayini.pdf

Turkey, Ministry of Food, Agriculture and Livestock. (2015). Red meat strategy. Directorate General of Livestock. Retrieved from https://www. tarimorman.gov.tr/HAYGEM/Belgeler/Hayvanc\%C4\%B1l\%C4\%B1k/ K\%C4\%B1rm\%C4\%B1z\%C4\%B1\%20Et\%20Stratejisi.pdf

Turkey. (2018a, December 28). Decision on the application of tariff quota for importation of livestock and meat (no. 518). Official Gazette of Turkish Republic. Retrieved from https://www.resmigazete.gov.tr/ eskiler/2018/12/20181228-5.pdf

Turkey. (2018b, February 26). Decision on Agricultural Support in 2018 (No. 2018/11460). Official Gazette of Turkish Republic. Retrieved from https://www.resmigazete.gov.tr/eskiler/2018/02/20180226-15.pdf

Turkey, Ministry of Agriculture and Forestry. (2019). Regulation on the classification of cattle carcasses (draft). Ankara. Retrieved from https:// www.tarimorman.gov.tr/HAYGEM/Duyuru/121/Sigir-KarkaslarininSiniflandirilmasina-Dair-Yonetmelik-Taslagi-Yayinlandi

Turkish Statistical Institute. (2018). Turkish statistical institute databases. Retrieved from www.tuik.gov.tr

Uçum, İ., \& Gülçubuk, B. (2018). Local industrial enterprises based on livestock production and problems in the process of contribution to the local economy. KSU Journal of Natural Sciences, 22(spe), 4454. http://dx.doi.org/10.18016/ksutarimdoga.v21i41625.472849.

Unnevehr, L., \& Bard, S. (1993). Beef quality: will consumers pay for less fat? Journal of Agricultural and Resource Economics, 18(2), 288295. http://dx.doi.org/10.22004/ag.econ.30964.

Verbeke, W., Van Wezemael, L., Barcellos, M. D., Kugler, J. O., Hocquette, J. F., Ueland, O., \& Grunert, K. G. (2010). European beef consumers' interest in a beef eating-quality guarantee: insights from a qualitative study in four EU countries. Appetite, 54(2), 289-296. http://dx.doi. org/10.1016/j.appet.2009.11.013. PMid:19961887.

Williamson, C. S., Foster, R. K., Stanner, S. A., \& Buttriss, J. L. (2005). Red meat in the diet. Nutrition Bulletin, 30(4), 323-355. http://dx.doi. org/10.1111/j.1467-3010.2005.00525.x.

World Health Organization - WHO. (2007). Protein and amino acid requirements in human nutrition. Genebra: WHO/FAO/UNU Expert Consultation. Retrieved from https://www.who.int/nutrition/ publications/nutrientrequirements/WHO_TRS_935/en/

Wyness, L. (2016). The role of red meat in the diet: nutrition and health benefits. The Proceedings of the Nutrition Society, 75(3), 227-232. http://dx.doi.org/10.1017/S0029665115004267. PMid:26643369.

Yavuz, F., Bilgic, A., Terin, M., \& Guler, I. O. (2013). Policy implications of trends in Turkey's meat sector with respect to 2023 vision. Meat Science, 95(4), 798-804. http://dx.doi.org/10.1016/j.meatsci.2013.03.024. PMid:23590993. 